UDK 78.038.6:784.55 Prince

Christian Bielefeldt

Institut für Kulturwissenschaft, Universität Lüneburg

Inštitut za kulturologijo, Univerza v Lüneburgu

\title{
Beyond Postmodernism? Prince and Some New Aesthetic Strategies
}

\section{Onstran postmodernizma? Prince in nekaj novih estetskih strategij}

Ključne besede: Prince, postmodernism, musicology, pop music, aesthetics

IZVLEČEK

Prejšnji Princov postmodernistični album $M u$ sicology (2004) ponovno uveljavlja avtorstvo in zgodovino, s tem da oživlja »resnično«, netehnološko zvrst glasbe na relaciji funka in hip-hopa. Članek odkriva, da gre pri tem za strategijo "refleksivnega modernizma", za estetiko, ki predstavlja izziv postmodernemu zanikanju ontologije $s$ pomočjo predhodnih - tako tudi označenih ontologij.
Keywords: Prince, postmodernizem, muzikologija, popularna glasba, estetika

AbStract

Former postmodernist Prince's album Musicology (2004) re-occupies authorship and history, evoking a "real", non-technological kind of music in the line of funk and hip-hop. The article is reading that as a strategy of "reflexive modernism", an aesthetic challenging the postmodern denial of ontology with interim ontologies marked as such.

\section{"Unmistakbly Prince"}

In 2000, the Artist known as Prince while noted for producing his music under variable names and symbols returned to his most common brand name. Since 2004 he even reverted to collaborations with major record companies (Sony, Universal) that he emphatically had avoided for years, celebrating his new freedom in 1996 with his first independent NPG-production, a three-CD-box significantly called Emancipation. The result of this comeback as a global superstar are two enormously successful albums until now, Musicology (2004) and 3121 (2006). While the first reached top five in US, UK, Australia, Germany and many other countries, the latter actually became Prince's first \# 1 on billboard album charts in seventeen years (the 1989 Batman sound- 
track being its predecessor). Interestingly, Musicology was celebrated even as his long expected - and true nostalgic - return to his unmistakably home. ${ }^{2}$ A notion that must appear surprisingly romantic in the case of Prince, so far dealt as a current example for post-modern practices in popular music.

However, what I want to discuss in this article is not so much Prince's reconciliation with the global music industry sharply rejected before, but the conceptual difference between Musicology and most of his earlier work, including the mainstream crossover records of the eighties and the Warner-releases in the early nineties. The article argues that this difference basically depends on a new relationship to the past, and to pop history in particular: Constructing linear historical references and inscribing itself in a selected stream of pop history, Musicology's association to the past of pop is not, or at least not longer predominantly post-modern. It has to be considered then, in how far this new historiographic Prince, being unmistakable, also affects the question of authorship anew. A crucial question in that Prince is commonly classified as a blueprint of postmodernism's cancellation of the author in the field of popular music. $^{3}$

The following discussion ties up to this aesthetic debate, suggesting that the historiographical lineament of Musicology cannot, or should not be shortened to the conditions of a major contract in the middle 2000's. Indeed, copying Madonna's Hung up (2005), the appeal of nostalgia is increasingly used as marketing method for aging stars who reject the as-if-I-were-young-attitude of Jagger \& co but do offer to be part of a community celebrating a brilliant past. Such economical reasons surely exist, as Christina Aguilera's retro-album Back To Basic (2006) indicates. And I am far from denying them completely in the case of Musicology, given Prince's practice of best-of concerts in the preceding years and also the rumour that his Paisley Park Studio had serious financial problems (Brown 2004). With Sony, Prince could count on global distribution while maintaining copyrights, which he did not keep hold of with Warner. The article yet dissects strategies on the album that advise an aesthetical evaluation: While using them, Musicology is critically reflecting the aesthetical and ideological impacts of nostalgia. To make this apparent as a strategy beyond postmodernism, I will first discuss some aspects of post-modern art and theory in general, facing them with options beyond.

\section{Interim ontologies: Postmodernism and beyond}

One of the reasons for the persistent success of post-modern theory likely consists in its rejection of linearity as scientific paradigm. Regarding aesthetics, the modern logics of linear progress are replaced by conceptions of spatiality and differentiation, both keywords of postmodernist thinking. The notion of innovation and transgression is redeemed by figures of ramification and recombination (the other keywords I 
want to pick up here). The advantage of these conceptions consists in the interpretations they deliver of crucial phenomenons of art in the second half of twentieth century. Asynchronism, plurality of material and the re-utilisation of older media-concepts in new contexts have in common that it is hard to grasp them in a modern perspective.

Prince, singer, multi-instrumentalist, composer and producer of many of his songs in personal union, can serve as a prime example for that in the context of popular music. Concerning his music, any valuation in modern categories must fail in so far it is peculiar not in developing new, progressive stylistic means and configurations, but in the play with crossover, the artistic juggling with stylistic standards and role models (Hawkins 1992). In a modern view, the absence of authentic elements as the elaborate recombination of pre-existent styles and the vexing ambiguous exposure to constructions of gender, sexuality and ethnicity must be valuated as merely eclectic, lacking of depth and originality. In contrast, a post-modern view catches this as just his artistic signature, lastly accounting for his dazzling image as a global pop diva (Danielsen 1997). And don't we remember his appropriation, excessive enhancement and at the same time cancellation of African American macho-clichés... They were post-modern however, only because they produced a strategic openness (the fifth and last keyword I will apply here).

What does ,openness' mean? According to Anne Danielsen (Danielsen 1997), it denotes the absence of an expressive centre that characterizes post-modern products (and Prince's music). On albums like Sign'O'The Times (1987), Lovesexy (1988) or Diamond E Pearls (1991), the position of the subject as the authority that produces expression is vacant, or anyway cannot be defined - it is open. To be more precise, authorship is openly replaced with changing symbols, styles, practices and discourses. Thus Prince's music is played from the position of a secondary observer (Luhmann 1999, p. 92-164) who is observing the respective strategies leading to the construction of expression. Might that be a conscious operation, as Hawkins postulates, or, following Danielsen, an unconscious. Definitely it prevents every attempt to perceive Prince's music as an authentic expression of a 'real' person hidden in the dark depth behind the artistic curtains (as Rock or Hip-Hop music normally does). The appropriation of styles, namely of Funk, Disco, Rock, New Wave, Jazz or Hip-Hop and their devolvement into the princean sound cosmos is at best transitory, one style replaceable through another or another combination of styles.

And that also defines the relation between Prince's music and history until Musicology. The stylistic allusion on his post-modern albums "does not point backwards" (Danielsen, p. 281), activating a network of historical references. It rather opens a space of signs and symbols on hand, in which concepts of linearity are just irrelevant. Funky elements and shivers of rock, synthetic pop and other popular styles are handled not as links to historical music cultures, but as interchangeable modes of expression. Time as a linear, continuing process thus is overridden - as it is in a imagination frequently evoked in Prince's songs and video clips of the 80s and 90s: An extended party filled with music, love, dance \& sex and situated in deterritorialized, phantastically endowed sites shortly before the end of the world. "I'd rather dance my life away" 
(Prince: 1999): As a metaphor for satisfied life it appears for the first on 1999 (1983) and can be found on many following albums and videos. Changing only in details, it over and over celebrates a hedonistic, imaginary club-landscape with joyous bands in coloured costumes between glamour and camp, addicted to timeless jam-sessions and altogether "runnin' outta time" (1999). The post-modern aspect here must be seen in the close combination this image contains. The celebration of dancing as the most intense state of life is an even premodern topos not only of popular music. But connected with an explicit concept of temporal spatialisation and exhaustion, facing the end of the world, it is mirroring the post-modern denial of linearity.

This leads us back to a more general level of discussion. It is easy to see that the suspensions of authorship and temporal linearity found in Prince's earlier work correspond with the post-modern challenge of the 'great narratives' of art and music history as sequences of styles and epoches. We have to consider this a while to get the point where options beyond postmodernism open up.

First, it is a critical problem that in the consequence of this challenge postmodernism cannot think its own historicity. As it is defined not only as a final step of, but a step out of history, a spatialisation of history in which every possible differentiation is already included, it is contradictory to reflect postmodernism as a mere historical stage. Evidence for that are rhetoric figures like 'the end of history' and 'the end of art'. Therefore, in a post-modern view, a delineation of aesthetical strategies beyond postmodernism conflicts with its own paradigms and must inevitably arouse suspicions of regression: Could we ask for aesthetics beyond postmodernism despite at least partial abdication of complexity and plurality? And could that be anything else than a retreat to undercomplex or even totalitarian positions? It could, according to the German philosopher Harry Lehmann (Lehmann 2006). I will pick up some of his assumptions here, transferring them to the popular music context.

Facing aging postmodernism and its loss of artistic and social potentialities, Lehmann concedes above all two possible options beyond, calling the first 'naive', the second 'reflexive'. Both are understood as variants of modernism and it is important to see that they initially have one thing in common: a turn from the post-modern aesthetic of material to aesthetics of representation or content. But whereas the naive modernism effectively drops back to banality, sentimentality and in general, spoken with the German sociologist Ulrich Beck, to a "hergestellte, herstellbare Fraglosigkeit. Genauer: Tilgung, Entsorgung der Frage, in die die Moderne zerfällt" (Beck, p. 59), ${ }^{4}$ the contents of reflexive modernism legitimately abolish the post-modern negation of the representative artwork. While the naive option retires to traditionalisms, remoralisations and simple distinctions, the reflexive modernism openly breaks with a decisive post-modern taboo. However, in recorded popular music with its close standards of song production, technology and distribution the question of the open, selfnegating artwork might not be as crucial as in the context of avant-garde music to which Lehmann is referring to. But his basic idea nevertheless seems convincing. Subsequently the critical difference between both options has to be found in the level of

Could be translated as: "to a disposal of the question, in which modernity decays". 
reflexivity that is perceivable in - or at least ascripted to - their products. While both reduce complexity to get clear distinctions and representations, the naive modernism is blind for (or even hides) this operation. By contrast, the semantic closures presented by reflexive modernism are at the same time marked as contingent, or, in other words, as interim ontologies (Fuchs 2004). But what could that mean for an album that should arouse musicological interest just with its title?

\section{Musicology}

As mentioned above, Prince's first major label album after years adopts a flashy new line not only in comparison with the NPG records of the last decade but also the Warner forerunners. ${ }^{5}$ Indeed the album again circles around the party-metaphor. The programmatic Life'O' The Party inherently demonstrates what the refrain of the title song underlines with an unmistakably imperative: "Keep the party movin' / Just like I told you". But significantly, this party is not longer situated in a timeless room of floating signs and styles. On the contrary, Musicology evokes a clear-cut cultural and stylistic context, framing a destined African American line of tradition that ranges from the funk artist James Brown and his brothers Sly \& The Family Stone and Earth, Wind \& Fire up to the hip-hop acts Doug E Fresh, Jam Master Jay and Chuck D (all quoted by name in the title song), Missy Elliot (The Marrying Kind), Dr. Dre and at last one experienced member of Prince's bands, the saxophonist Candy Gulfer (Life'O' The Party). Finally, if only by a short ironic remark on his nose, also Michael Jackson is present (Life'O' The Party). With this catalogue of famous black music and musicians Musicology indeed gets the character of a selected historiography of Funk \& Soul (including hip-hop) in which Prince is inscribing himself.

Similarly, the musical elements that reach beyond the funk/hip-hop tradition, as for instance 70's rock guitar playing (Cinnamon Girl) and folk-jazz instrumentation (Reflection), are little distinct in comparison with the leading role of full-funk-band style, p-funk jamming

Musicology
Head about the party now
Just east o' Harlem
Dougie's gonna b there
But u got 2 call him
Even the soldiers
Need a break sometimes
Listen 2 the groove ya'll
Let it unwind your mind
No intoxication
Unless you see what I see
Dancin hot n' sweaty
Right in front of me
Call it what u like
I'm gonna call it how it be
This is just another one
Of God's gifts
Musicology
Chorus: Keep that party movin
Just like I told you
Kích the old school joint
4 the true funk soldiers
Musicology
Wish I had a dollar
4 everytime u say
Don't u miss the feeling
Music gave ya
Back in the day?
Let's Groove
September
Earth, Wind and Fire
Hot Pants by James
Sly's gonna take you higher
Minor keys and drugs
Don't make a rollerskate jam
Take ur pick - turntable or a band?
They re losin
Advanced Body Movin,

Musicology

Head about the party now

Just east o' Harlem

But $\mathrm{u}$ got 2 call him

Even the soldiers

Listen 2 the groove ya'l

No intoxication

Unless you see what I see

Dancin hot n'sweaty

Right in front of me

I'm gonna call it how it be

This is just another one

Of God's gifts

Chorus: Keep that party movin

Just like I told you

Kich the old school joint

4 the true funk soldiers

Don't u miss the feeling

Music gave ya

Let's Groove

September

Sly's gonna take you higher

Minor keys and drugs

Don't make a rollerskate jam

If it Chuck D

or Jam. Master Jay

now what?

Cause we got a PhD in

Chorus

As his most successful album since Diamonds E Pearls, Musicology was awarded with a NAACP Image Award (February 2005) and the Vanguard Price and nominated for the best R\&B-album-Grammy 2005. In January 2005 it was certified with double platinum (Billboard/USA). 2004 The Rolling Stone readers voted for Prince as best male performer and most welcome comeback. 
and R\&B-ballad types. There is the programmatic title song with its canny riffs played by guitar and horn section, the very much JB-alike funky arrangement and a singing for which Prince was awarded with the Grammy for Best Traditional R\&B Vocal Performance in 2005. In the first shots of the video clip it is encircled by Claire-Fisherstrings, corresponding with the sepia colours of the record shop site and the little boy's afro. There are three love-songs with R\&B crooning style singing, slow but bright bass lines and organ and soft background string throw-ins that are much evocative of 70's Bobby Womack or Al Green ballads (A Million Days, Call My Name and the ironic bluesy On The Couch, the leading vocal part sung completely in high falsetto, assisted by male background voices). And there is the mid-tempo funky ballad What Do $U$ Want Me 2 Do with a fine guitar hook and quick riffs of the bass guitar, the souly The Marrying Kind, featuring important roles for organ and lead guitar, the mid-tempo If Eye Was The Man In Ur Life with objections of the full horn section, synthesizer parts and singing in two and more vocal-lines, and the flute and handclaps of Reflection, all the four about living the somehow profane life as a husband. Finally, besides the straight rock guitar epos Cinnamon Girl there is another song engaged with social critic and current political topics (as the second verse of Call My Name is): Dear Mr. Man, characterized by short horn and guitar riffs, organ chords and a descending bass-line unmodified played throughout the song.

Sure these songs feature some characteristic elements of Minneapolis Sound: the dry and highs-orientated sound-mix with less dominance of the bass than in traditional funk; the synthesizer replacing horns and playing rather short accents than extensive background lines; the use of guitar-solos in a rock style, sometimes distorted. But, they are striking less dominant than in most of Prince's former music and overall drowned out by the elements of 70's black music just described, the period when young Prince Rogers Nelson grew up, began to perform and made his first records. However, like a reflection on James Brown's initial irritation about the sampling practices of hip-hop, there is only one song with a valid rap part on the album (Pimp, Illusion, Coma \& Circumstance). Facing the respectful reverence to the hip-hop tradition just mentioned, this is striking less than on albums like Emancipation and even Diamond E Pearls. I will suggest an interpretation for this later on.

Interestingly this new relationship to pop history is accompanied by a new position of Prince's voice. Produced noticeably non-varying in comparison to the manifold vocal masquerades on the post-modern albums, his voice recaptures the centre of his music as a sound identity. However, strictly speaking, it is again not the 'real' Prince we are invited to hear. In turn there is no authentic space besides the media product (and this might be a continuity to the post-modern Prince who used to play with these spaces as media effects). Rather, while evoking several R\&B vocal styles and sounding old-fashioned 'natural' not only in its registers and timbres but also in its constant place in the acoustic centre, the vocal part concurrently represents the somehow abstract voice of the black music tradition. This becomes obvious also in the clip of the title song, where he dominates the scenery as he wants. Significantly, he is introduced not so much as a person, but, corporating a past of brilliant black music, as a type, the African American soul star representing black power and energy. Dressed 
in old time costumes and performing a little in JB-manner, Prince appears as a concept, corporating the history of 'real' black funky music altogether. Thus, adored by the audience in a quasi religious way, the central position of the subject on Musicol$o g y$ is not only retaken, it is even enlarged to a fetish. The centre of Prince's music is re-occupied, but not by a self-expressing romantic subject, but rather an abstract conception. On Musicology authorship is a matter of ideology.

\section{Real music to bring the spirit back}

As we have seen, both post-modern criteria mentioned above - the loss of the author and spatialisation of history - are largely absent on Musicology. Hence, as the album is (re)constructing linearity, it might be difficult to value it any longer in the categories of postmodernism. But does that already mean it's adequate to appraise the album as a felicitous traditionalism, in line with international critics? ${ }^{6}$ Is $\mathrm{Musicol}$ ogy a mere product of naive modernism? I must concede that some reasons vote to confirm this suspicion. A glimpse on the lyrics of the title song is enough to assess that the reminiscence of the funk tradition indeed goes ahead with simple distinctions and a quite strict remoralisation (flags of naive modernism as shown above). According to the crucial position of the formula 'old-school-joint', the distinction between good and evil is not only quite simple, but definitive too: On one side we have the soul survivors, the good and true funk soldiers who don't need any other drugs than old school 'real' music (including the boy playing the hoover-mike in the video), while on the other the bad guys, fallen into the vicious circle of drug abuse and violence. Accordantly, the forth song makes clear that the invitation to party all-night implys a strict assignment from those who don't follow it (and do wrong): "We ain't down with nobody / That don't party like we do / [...] This is the life'o' the party / We gonna do it right".

Furthermore, a second simple (and nostalgic) distinction corroborates this musically. It is drawn with the predominance of acoustic sounds and the abdication of audio-technological effects not only concerning the voice, but nearly all tracks of the album. In fact Musicology appears like a phonographic essay on live-music with predominantly acoustic instruments. Applications of openly computer processed sounds are reduced to a quite small amount, giving place for the electric funk guitar and the organ, horns, piano and other acoustic instruments as for instance the Clare-Fisherstrings earlier spoken to or the flutes in Reflection. And, not least, the stereo sound of most songs on Musicology is arranged as an effigy of a live performing situation, lightyears away from the elaborate overlapping of sound planes, voices and tracks that consistently creates and combines artificial spaces for instance on Emancipation (with the significant exception of Pimp, Illusion, Coma and Circumstance I will discuss later on). Prince thereto stated on German TV: "We think of it as trying to bring real music back, real musicians playing real music. A lot of pop music today is computer gener-

For the German reviews, s. in addition http://www.purple-net.de/ArtikelMusikology.html. 
ated. A lot of the concerts are not even live performances they're prerecorded performances and we just want to kind of bring the spirit back" (Prince 2004). ${ }^{7}$ An idea that becomes an ideology with the either-or-question in Musicology ("Take ur pickturntable or a band?") and particularly in Life'O' The Party, suggesting to destroy the hardware of popular music: "Throwin' records out the window / CDs out the door/ Might as well giv'em 2 the milkman / cause we don't want em no more //“. Adjacent the next verse specifies sensual body experience as the unique form of musical perception, picking up a prominent 'white' discourse about black music and musicians: "Everybody can smell this funk u'all / Even down in Atlanta, GA."

Even the fundamental marketing idea of Musicology can be taken as an element of this concept. Unlike normal music business, it was focused on the live performance, turning over a record for free to every buyer of a concert ticket (as shown in the Musicology-clip). ${ }^{8}$ The record and video clips consequently are if not destroyed but getting the status of secondary products, just appended to the live musical performance.

Facing this it seems anything but wrong to state that Musicology primarily reproduces a tradition-bounded African American self-depiction, combining an idea of proper black life with the aesthetic of a live spirited black musical practice. However, the naive aspect here must be seen alone in the fact that after all the 'authentic' sound of the album gets so convincing because of the extensive technological means of the four studios involved and named in the CD-cover, Prince's Paisley Park Studio in Chanhassen, Minneapolis, the canadian Metalworks Studio, Bernie Grundman Mastering and the Hit Factory, New York. Not only that Claire Fisher's string arrangements are digital samples added to the other sequential tracks of the songs (as confirmed in the booklet). On the record, like an ironic comment to the statement just quoted, precisely the very 60's or early 70's funkalike horn section part in the title song is replaced by synthetic computer-generated sounds - a replacement, as mentioned above, known to be a crucial earmark of Prince's Minneapolis Sound since the 80's. And even a 'natural' sound like that of the vocal parts on Musicology, to be sure, nowadays is a artificial and highly technological product, addicted to extensive computer processing simulating a non-computerized recording.

\section{Reflexive modernism on Musicology}

These incongruencies between concept and product at least question the evaluation of the album as entirely traditionalist and nad've (in terms of Lehmann's modernist options). And, to be precise: for an artist and producer known for the virtual

On his german Musicology-homepage Prince is cited with the subsidiary statement: "Ich bin von Herzen Musiker und Künstler - das ist mein Beruf. ,Musicology' hat keine Grenzen und passt in kein Format. Es ist die ueberfällige Rückkehr zu Musik, Kunst und Handwerk - darum geht es bei diesem Album. Schools in Session!" (http://www.musicology.de/start.htm, visited 20.9.06).

8 Amongst others, this practice - the ticket thus containing the price of the record - was firmly criticized by the billboard editorial office. But, facing the ideology behind, even the fact gets less asthonishing that the title song was single-published only in Austrialia. 
overproducedness of his music, a concept of traditionalist, non-computerized live music indeed would widely challenge his own principles. The extensive jamming often practiced during performances and also on recorded versions of his songs (s. Anna Stesia, as analyzed by Hawkins 1992) has always been only one side of Prince's work, the lavish sound production the other. Accordingly, Musicology's certifications indicate three complete songs and the major part of the rest as played by Prince on its own, continuing his multitracking recording technique established more than 25 years ago. And it is hardly accidental that he released only one live-album during his whole career (One nite alone... live!, 2002) and continued to record without any collaboration after Musicology, as in the case of S.S.T. and the instrumental Brand New Orleans, both produced in the aftermath of the hurricane Katrina demolishing New Orleans, August 2005.

Thus, considering Musicology as the album on which Prince is "proving once again that he's about the only musician who can make a one-man band sound as vibrant as a live nine-piece group" (Erlewine 2004) - in other words, is using production technology as always in a very advanced way - , my doubts are deep. Finishing, I will present few but important media-reflexive, narrative, textual and musical elements on the album that foil or at least reflect its nostalgic touch.

Take for instance the fade-out sequence after the jamming part of the title song, enclosed only in the CD version. We are hearing crackling snippets of music here, including fractions of Prince's 80's hits Kiss (1984), Sign O' The Times (1987) and Little Red Corvette (1982) that are interrupted by pounding bass notes and male talk. Sounding in noisy mono standard, these short fragments commemorate the typical soundscape produced by the switching between stations on an analogue radio set (and every station is playing Prince). Thus reactivating the old technology sound signature, they create an acoustic retrospection with which technology itself becomes nostalgic. Concurrently, the digital imitation of analogue play-back technology marks media technique as a precondition for nostalgia. Records (and radios) thrown out the window or given to the milkman, we wouldn't have even the opportunity to know let alone hear - the music 'back in the days'. Recordings might be secondary to the intensity of life we feel while dancing at live music parties. But even a live concert tributed to the heroes of real music is senseless without the knowledge about their music. Alone on this account Musicology seems to me a really fitting album title. The album's topic is just not the party for its own, but together the documentation and knowing celebration of the past, reconstructing linearity between today and then (a past to which the song snippets add the 80's story of Prince's outrageous concerts with incredible excessive stage performances). Thus the memento of the radio switching reflects a blind spot of Musicology's nostalgia: the inseparableness of nostalgia and media technique. Or, in the words of the last song on the album, Reflection: "Can U turn up the stereo? / Eye wanna play U this old song / It's about love". In the field of popular music, it is technology that produces the synchronism of distance and reproduction we need to enjoy nostalgia.

Musical hardware becoming an object of desire is also the issue of the second element I want to introduce. It's a short, spoken byplay in the video clip of Musicology 
beginning at 2'51", few seconds from the closing jam-part. In his room draped with posters of Sly and other funk artists, the young protagonist gets into trouble with a man, probably his father, about some records. Apparently they belong to daddy (the record above is the Earth, Wind \& Fire album Spirit from 1976). Not surprisingly, after some moments the father masters the situation. Snapping up the albums, he ceases the battle with the definite words: "These are my records!" (3'00"). Evidently, he is not feeling up to let his son participate on his musical world, player and records being too precious to share: "Don't touch my stereo!" (2'58"). What in the first example seems to be only a matter of correct handling (adjusting the mono position), then turns into a question of possession, reflecting the ideological character every music ascripted as 'real' and distinct to any other must get. During the fight between son and father the records become a fetish that apparently pertains to the economical category of ownership and not to the social of participation. However, as we know from the lyrics of Musicology, this fetish is a gift of god: "I'm gonna call it how it B / This is just another one / of God's Gifts - Musicology". A second fraction of the clip demonstrates that it's impossible to share this gift without running the risk to loose the cohesion of the community it constitutes.

Arguing not in the register of possession but of space, this subplot demonstrates the traps of a hortus conclusus based on simple distinctions. As an ideological space, the home of 'real' music always is threatened. At 1'33" we see two adolescents trying to get into the concert hall, probably young rappers with a typical, rather easy-going outfit of old school hip-hop (too long t-shirts and sportswear, cap, 70's rayon jacket). It soon becomes clear that they will not succeed, the doorkeeper strictly preventing their entry. Yet in case we suppose lacking tickets as the reason, we are told better only twelve seconds later. The group of smart middle-aged and a bit gangster-like behaving, extremely well dressed blacks appearing at 1'45" also don't show the black ticket we have in mind from the little boy buying it at the outset. As they anyhow get access with a little help of a dollar note, this short scene is adding an unattended critical sight on what's going on. Obviously the discrimination between the inside crew of dancers and those forced to stay outside relies on dubious reasons. Bare money as a criterion conflicts deeply with hip-hop being part of the tradition the song is celebrating. So why aren't the rappers allowed to enter nevertheless? Is it the alterity becoming apparent in their eye-catching dress too different in the domain of the funk soldiers, mirroring the artistic alterity that early hip-hop inserted in the story of 60's and 70's black music? Read that way, the scene could be understand as a reference to the transient blindness of traditional black musicians for the young innovators out of the Bronx, who theirselves but adored their predecessors (and sampled their works over and over again). Furthermore, the album title then could be read also in terms of a privileged knowledge. As the title song says: "If it ain't Chuck D / Or Jam Master Jay / Know what? / They're losin' / cause we got a Ph.D. in / Advanced body movin'“, only the true soldiers know about the one and real music you can dance to. But this music then, this is the cue both scenes offers, is no longer a prior hedonistic practice, but a subject of knowledge and possession with regularized access. 
It's worth to glance secluding at a third little scene of the video. Meanwhile guarded by heavily armed security men, the singer is throwing another fetish to the audience just before he leaves the hall (beginning at 4'40"). And of course it is the young protagonist who catches the black and white handkerchief, wet by the real sweat of his hero. The point here is not only that the continuousness between the present, celebrating past, and the future therewith seems assured, dignifying the young listener as a privileged member of the funk soldiers community and actually a possible successor of his idol. In so far the enthusiastic boy appears as the little Prince Rogers himself, taking his youth inspirations from the conceptual hero the adult Prince is representing singing $M u$ sicology, the scene finally constructs a sort of time-warp in which the observer coincides with his object. The circular structure of this setting is evident. In his two roles Prince corporates past, presence and future of 'real' music, excluding every possibility of alterity. Much in contrast to the open, heterogeneous spaces of decontextualisated symbols and practices the post-modern spatialisation of time produces, Musicology establishes a recontextualisated place with hermetic borders to outside world.

My suggestion is to take these rather unimposing but anyway very significant moments of Musicology as elements of a second observation that observe (or reflect and even criticise) the first observation of black music practice the album and not least Prince's verbal statements are producing. In this view, we can understand Prince's overall surprising pleading for 'real' live music as a part of a basically concept, in which the challenge of the live-ideology is already included. As discussed above, a reflexive, self-challenging use of media and concepts is a truly post-modern strategy. But, in the case of Musicology, the result is not openness, decontextualisation and the disappearance of authorship. The reflexive elements I just introduced are rather little details, probably overheard by the majority of Prince's audience and apparently many critics too. They don't really challenge the abstract authority of traditionalist black music ideology, together documented and embodied by Prince. However, they exist, and in my perspective as elements of reflexive modernism: an aesthetic representing content (the funk tradition, the live-music concept, the current political topics) presented as contingent (reflecting the distinctions and ideological effects underlying). Musicology then appears as a sort of test arrangement that shows the achievements but at the same time the artistic and social blindness of a concept with only ears for the past.

"U know what? / Turn the stereo back down / Ain't nothing worse than an ole' worn-out love song" - that's the interesting statement Reflection offers in the end of the album.

Concluding, the question lasts why Pimp, Illusion, Coma E Circumstance is the only song with a veritable rap part and, resembling much more the old pastiche-style of post-modern Prince, detaches from the stylistic continuity of the album. The lyrics of this song discuss the difficulty to decide "who is pimping who" in a case where both have their advantages and "no second chance". Doesn't the song then implicitly reflect the album as a result of circumstances, due to them Prince is in a way 'pimping' for economic reasons (his music fallen into a naive, nostalgic coma, being prepared for global distribution and major label needs)? Anyway, also in this case it should count 
for Prince that he did not forget to document and reflect the agility and great merits of black music in a brilliant decade.

But in my view the album does more, demonstrating at least the possibility of aesthetic options beyond postmodernism: non-regressive strategies of content, working with temporary ascriptions and recontextualisations while challenging the postmodern taboos of linearity, meaning and closeness.

In a way, the best argument for my doubts about Prince's live-music-concept may not be found on Musicology itself, but on the following album. Disregarding few songs like the Latin pop trivia Te amoro corazon, style, sound and production aesthetics of 3121 widely revocate the centric idea of the former album. Picking up again the metaphor of the last, grand party ("We gon' party like there ain't gonna be another one", 3121) the acoustic and non-technological sound of 70's black music is largely reduced and, with few exceptions, substituted by just a return of explicit computer generated tracks, elaborately mixed with voice samples, futuristic electronic whimpers and abstract noises. When Musicology (re)constructed the 'nature' and unmistakability of Prince and his cultural home, the home to which 3121 invites us is above all highly artificial. In particular this affects the vocal tracks. Prince's voice is not only producing a much broader variety of registers and vocal sounds. Following the technically alienated voice on 1999 (and the de-gendered on If I Was Your Girlfriend, 1987), just a socalled 'true black' vocal technique as the gospel-melisma is digitally overworked and even audibly screened, demonstrating the artistic fertileness of advanced media technique and the constructedness of every vocal sound and personality (3121). Might Musicology at least partly be a naive, nostalgic "lesson in music" (Lundy 2004) of old times. 3121 then, as rumour has it the number of real Prince Rogers Nelson's villa in Hollywood Hills, definitely sketches another sight: Even Prince's affiliation to the ancient black music practice was a question of temporary ascriptions and interim ontologies.

Then expect the next...

\section{Bibliography}

Beck, Ulrich (1987): "Das Zeitalter der Nebenfolgen und die Politisierung der Moderne“, in: U. Beck et al (Hg.): Reflexive Modernisierung. Eine Kontroverse, Frankfurt a. J.: Suhrkamp 1996.

Brown, Ethan: "A New Reign. Prince has been disappointing for a decade. But just when expectations could hardly scrape any lower, he has made a great record," (New York Magazine), April 26, 2004 issue) on http://www.newyorkmetro.com/nymetro/ arts/music/pop/reviews/n_0206/, visited 26.9.06.

Danielsen, Anne (1997): "His name was Prince: A study of Diamonds and pearls", in: Popular Music, Vol. 16; Issue 3; Oct 1997; pp. 275-291.

Erlewine, Stephen Thomas (2004): "Musicology - review", on http://www.allmusic. $\mathrm{com} / \mathrm{cg} / \mathrm{amg} . \mathrm{dll}$ ?p=amg\&sql=10:o047gjqr46ia $\sim$ T1, visited 19.9.06.

Fuchs, Peter (2004): Der Sinn der Beobachtung. Begriffliche Untersuchungen, 2. Auflage, Weilerswist: Velbrück Wissenschaft. 
Gennoe, Dan: "Prince - 'Musicology'“, on: http://uk.launch.yahoo.com/040507/33/ 1wms4.html (written Friday May 7, 2004 4:10 PM), visited 29.9.06.

Hawkins, Stan (1992): "Prince: Harmonic analysis of Anna Stesia", in: Popular Music, Vol. 11; Issue 3; Oct 92; pp. 325-335.

Luhmann, Niklas (1999): Die Kunst der Gesellschaft, Frankfurt am Main: Suhrkamp Lundy, Zet: "Musicology - review", on http://www.popmatters.com/music/reviews/ p/prince-musicology.shtml, visited 2.10.06.

Prince (2004): Interview in the German broadcasting "leute heute" (ZDF), 4.5.04.

\section{Povzetek}

V devetdesetih so o Princu razpravljali kot o primeru postmoderne zvrsti popularne glasbe, pri čemer so izpostavljali njegovo "nabiralniško paberkovanje" različnih stilov in njegovo igranje, večkrat zakrito tako glede spola kot etičnosti. Njegova glasba naj ne bi nudila nobene samolastne "globine", ki naj bi bila značilnost rock glasbe, ampak naj bi predstavljala poigravanje s stilnimi standardi in modeli različnih vlog. Prav tako so bile uporabljene razne prakse in popularni stili, oboje v smislu zamenljivih načinov izraza. Princovo glasbo je označevalo pomanjkanje izhodišča in časovne kontinuitete, ni imela značilnega zvoka, ampak je predstavljala pasticcio različnih zvočnih značilnosti. Princov album Musicology pa se vrti okoli teh postmodernih vrzeli na drugačen način.

Musicology ne upošteva samo določenih korenin, $\mathrm{s}$ tem da navaja imena in albume raperjev stare šole ter posamezne ansamble, in uvaja določen subjekt, pevca kot junaka in hkrati kot verodostojen glas črnske tradicije. Album se ukvarja in ustvarja tudi časovno kontinuiteto med časi stare šole in "resničnimi vojaki« sedanjosti. Ker funk pesmi, ljubezenske balade in pesmi s politično vsebino sekajo določeno tradicijo "črne glasbe«, bi bilo možno označiti album kot produkt "naivnega modernizma» (H. Lehmann 2006), kot nostalgičen in ne nazadnje ideološki korak nazaj h koreninam tako imenovane avtentične, akustične in večinoma netehnološke žive prakse soula \& funka sedemdesetih, kakor so izdelke označili mnogi kritiki. V nasprotju s takšnim gledanjem članek zagovarja mnenje, da mnoge podrobnosti albuma kažejo na določeno estetsko strategijo, ki zaobsega in preoblikuje nasprotja med stališči onstran postmodernizma; kaže na »reflektirajoči modernizem", to je na (za)obrnitev k estetiki vsebine, v nasprotju s postmoderno estetiko gradiva. Videoklip izpostavlja misel, da mora vsaka skupnost oziroma vsak "dom" »resnične " glasbe biti odporen proti novotarijam in spremembam. V tem smislu album "3121"iz leta 2006 gradi Princov »dom« kot popolnoma umeten in visoko tehnološki konstrukt. 